\title{
Assessment of $\beta$-D-Glucosidase Activity from Two Typical Strains of the Lactic Acid Bacteria, Oenococcus oeni, in China
}

\author{
Y.H. Li ${ }^{1}$, M.T. Fan ${ }^{1 *}$, G.Q. Zhang ${ }^{1}$, Y.L. Liu ${ }^{2}$ \\ (1) College of Food Science and Engineering, Northwest A \& F University, Yangling, Shaanxi, 712100, China \\ (2) College of Enology, Northwest A \& F University, Yangling, Shaanxi, 712100, China
}

Submitted for publication: January 2012

Accepted for publication: March 2012

Key words: Oenococcus oeni, $\beta$-D-glucosidase, localisation, characterisation, wine

\begin{abstract}
$\beta$-D-glucosidase $(\beta G)$ is one of the most interesting glycosidases for the hydrolysis of glycoconjugated precursors to release active aromatic compounds in musts and wines. Oenococcus oeni strains SD-2a and 31MBR are widely used in Chinese wines to reduce the acidity. In the present study, the $\beta G$ activity of the two strains was localised and partially characterised using synthetic substrate. The activity occurred in whole cells, sonication supernatants and debris, but not in the culture supernatants for both strains. Whole cells of strain SD-2a possessed greater $\beta$ G activity, while strain 31MBR showed higher enzyme activity in the sonication supernatants. Strain 31MBR exhibited higher total enzyme activity than strain SD-2a. The optimum temperatures for $\beta \mathrm{G}$ from the two strains were $40^{\circ} \mathrm{C}$ at $\mathrm{pH} 3.5$ and $50^{\circ} \mathrm{C}$ at $\mathrm{pH} 5.0$, respectively. Ethanol at low concentrations had a positive effect on $\beta$ G activity in both strains, while a wine-like pH (3.5) decreased the enzyme activity to a great extent. Whole cells of strain SD-2a showed the highest activity among all samples tested under wine-like conditions. Thus, strain SD-2a proved to have potential for aroma improvement in winemaking.
\end{abstract}

\section{INTRODUCTION}

The aroma and flavour compounds present in wine are derived mainly from grape berries, although many of these volatile compounds are also produced during fermentation, such as monoterpenes, $\mathrm{C}_{13}$-norisoprenoids, benzene derivatives, aliphatic alcohols and phenols (Maicas et al., 1999; Mateo \& Jimenez, 2000; Bartowsky et al., 2002; D'Incecco et al., 2004; Michlmayr et al., 2010a). It is well known that a significant part of flavour remains as odourless glycosylated precursors in newly made wine that are not hydrolysed during ethanol fermentation. These odourless precursors containing aroma aglycones are not directly accessible to the olfactory mucosa, but may greatly affect wine quality after hydrolysis (Williams et al., 1995; McMahon et al., 1999). The hydrolysis of odourless precursors could be achieved through chemical or enzymatic treatment during winemaking. However, the acid hydrolysis occurs quite slowly, and may produce undesirable and unpredictable flavours. Alternatively, enzymatic hydrolysis is a favourable method to enhance the natural aroma spectrum of wine without detrimental effects on the final quality (Spagna et al., 1998; McMahon et al., 1999; Mateo \& Jimenez, 2000; Michlmayr et al., 2010a).

$\beta$-D-glucosidase $(\beta \mathrm{G})$ is one of the most interesting glycosidases to hydrolyse glycosylated precursors, releasing active aroma and flavour compounds (Spagna et al., 1998;
Barbagallo et al., 2002; Palmeri \& Spagna, 2007). Recently, an increased interest in the sources of $\beta \mathrm{G}$ has been focused on lactic acid bacteria, especially Oenococcus oeni, the main bacterial species that conducts malolactic fermentation (MLF) in winemaking, as $\beta \mathrm{G}$ activity from grape and yeasts is limited in winemaking (Maicas \& Mateo, 2005; Palmeri \& Spagna, 2007; Saguir et al., 2009; Michlmayr et al., 2010b). Numerous investigations have been conducted of $O$. oeni strains, providing evidence of the potential $\beta \mathrm{G}$ activity for flavour enhancement in wines (Grimaldi et al., 2000; Boido et al., 2002; Mansfield et al., 2002; Ugliano et al., 2003; Barbagallo et al., 2004b; D'Incecco et al., 2004; Grimaldi et al., 2005a; Bloem et al., 2008; Michlmayr et al., 2010a; Gagné et al., 2011). It has been reported that possession of glycosidic activities was widespread and strain-dependent in these strains commonly used for MLF in winemaking (Grimaldi et al., 2005b). Yet among all of this research there is not much about the enzyme localisation and its characterisations under oenological conditions.

Recently, the consumption of wine, especially red wine, has shown an increasing trend in China. However, wines made in China are usually characterised by low $\mathrm{pH}$ and a bland flavour due to the climate and cultivars. Thus MLF is necessary and the selection of starter cultures possessing important oenological characteristics is significant for the wine industry in China. Oenococcus oeni strains SD-2a and 
31MBR have been isolated and widely used in winemaking in China. Up until now, little information has been available on the $\beta \mathrm{G}$ activity of both strains.

The aim of the present study was to localise $\beta \mathrm{G}$ activity within $O$. oeni strains $\mathrm{SD}-2 \mathrm{a}$ and $31 \mathrm{MBR}$ and partially characterise the enzyme under different physicochemical conditions.

\section{MATERIALS AND METHODS}

\section{Bacterial strains and cultivation}

Oenococcus oeni strains SD-2a and 31MBR, stored in our laboratory, were used in this study. Both strains were cultivated in acidic tomato broth (ATB) medium containing $10 \mathrm{~g} / \mathrm{L}$ glucose, $5 \mathrm{~g} / \mathrm{L}$ yeast extract, $10 \mathrm{~g} / \mathrm{L}$ peptone, $0.2 \mathrm{~g} / \mathrm{L}$ $\mathrm{MgSO}_{4} \cdot 7 \mathrm{H}_{2} \mathrm{O}, 0.05 \mathrm{~g} / \mathrm{L} \mathrm{MnSO} \cdot 4 \mathrm{H}_{2} \mathrm{O}, 0.5 \mathrm{~g} / \mathrm{L}$ cysteine $/ \mathrm{HCl}$ and $250 \mathrm{~mL} / \mathrm{L}$ tomato juice. The $\mathrm{pH}$ of the medium was adjusted to 4.8 with $\mathrm{KOH}$. Bacterial cultures were prepared by inoculating $1 \%(\mathrm{v} / \mathrm{v})$ of preculture into $100 \mathrm{~mL}$ of ATB medium and incubating at $25^{\circ} \mathrm{C}$ until the value of $\mathrm{OD}_{600 \mathrm{~nm}}$ reached about 1.90 (the late exponential growth phase).

\section{Sample preparation}

Bacterial growth was monitored by measuring $\mathrm{OD}_{600 \mathrm{~nm}}$ until the end of the exponential growth phase (about $80 \mathrm{~h}$ and 40 $\mathrm{h}$ for strains SD-2a and 31MBR, respectively). Cultures of $1 \mathrm{~mL}$ were centrifuged at $5000 \mathrm{x}$ for $20 \mathrm{~min}$ at $4^{\circ} \mathrm{C}$ to collect supernatants and whole cells. Whole cells were washed twice with $1 \mathrm{~mL} 150 \mathrm{mmol} / \mathrm{L} \mathrm{NaCl}$, then resuspended in $1 \mathrm{~mL}$ cold aseptic distilled water for the enzyme assay. The supernatants and washes were used directly to determine $\beta \mathrm{G}$ activity. For the determination of intracellular enzyme activity, whole cells that had been washed were resuspended in $1 \mathrm{~mL}$ PBS $1 \times$ buffer $(140 \mathrm{mmol} / \mathrm{L} \mathrm{NaCl} ; 2.7 \mathrm{mmol} / \mathrm{L} \mathrm{KCl} ; 10 \mathrm{mmol} / \mathrm{L}$ $\left.\mathrm{Na}_{2} \mathrm{HPO}_{4} ; 1.8 \mathrm{mmol} / \mathrm{L} \mathrm{KH}_{2} \mathrm{PO}_{4} ; \mathrm{pH} 7.4\right)$, sonicated for 20 $\mathrm{min}$ in an ice bath using a sonicator (Hielscher $\mathrm{GmbH}$, Germany) at $100 \mathrm{w}$ and centrifuged at $14000 \mathrm{x}$ g for $15 \mathrm{~min}$ at $4^{\circ} \mathrm{C}$. The resulting debris was washed twice with $1 \mathrm{~mL} 150$ $\mathrm{mmol} / \mathrm{L} \mathrm{NaCl}$ and resuspended in $1 \mathrm{~mL}$ cold aseptic distilled water for the enzyme assay. The corresponding supernatants and washes were used directly to determine enzyme activity. The enzyme assay was also conducted on disrupted lysate (solution of whole cells treated with sonication) containing intracellular $\beta \mathrm{G}$, either soluble or attached to the ruptures.

\section{Enzyme assay}

$\beta \mathrm{G}$ activity was determined spectrophotometrically using $p$-nitrophenyl $\beta$-D-glucopyranoside ( $p$-NPG, Sigma cat no. N7006) as the substrate according to a method described previously with some modifications (Barbagallo et al., 2004b). To yield a final absorbance value of between 0.2 and 1.0 at $400 \mathrm{~nm}, 200 \mu \mathrm{L}$ of the sample was diluted with distilled water to $500 \mu \mathrm{L}$. Reaction mixtures were made by the introduction of each diluted sample into $500 \mu \mathrm{L} 2$ $\times$ citrate-phosphate $/ p-\mathrm{NPG}$ solution with a final $\mathrm{pH}$ of 5.0 and a substrate concentration of $5 \mathrm{mmol} / \mathrm{L}$. Incubation at $30^{\circ} \mathrm{C}$ for $1 \mathrm{~h}$ was followed by colour development. In order to minimise the spontaneous hydrolysis of the substrate under alkaline conditions, which are necessary for colour development, the mixtures were first centrifuged at 14000 $\mathrm{x} g$ for $15 \mathrm{~min}$ at $4^{\circ} \mathrm{C}$ to remove cells or debris, after which the supernatants were transferred immediately into 2 $\mathrm{mL}$ of $1 \mathrm{~mol} / \mathrm{L} \mathrm{Na}_{2} \mathrm{CO}_{3}$ to stop the reaction and allow the development of the yellow colour of $p$-nitrophenolate ion. A blank was prepared using distilled water instead of samples, but otherwise treated in the same manner. The absorbance of the yellow $p$-nitrophenolate ion was measured at $400 \mathrm{~nm}$ with a $1 \mathrm{~cm}$ cell in a Beckman DU-800 spectrophotometer. The concentration of liberated $p$-nitrophenol ( $p$-NP) was calculated from a calibration curve prepared from a series of standard $p$-NP solutions containing 0 to $100 \mu \mathrm{mol} / \mathrm{L} p$-NP $\left(\varepsilon_{400}=6000 \mathrm{~L} / \mathrm{mol} / \mathrm{cm}\right)$. One unit of enzyme activity was defined as $\mu \mathrm{mol}$ of $p$-NP released per min per gram of cell dry weight. All assays were performed in quadruplicate for both strains.

\section{Assessment of enzyme activity under different physicochemical conditions}

Disrupted lysate of both strains SD-2a and 31MBR, as well as whole cells of strain SD-2a, were used to study the influences of temperature, ethanol and $\mathrm{pH}$ on $\beta \mathrm{G}$ activity. For the influence of temperature at different $\mathrm{pH}$, assay mixtures at $\mathrm{pH} 3.5$ (a wine-like $\mathrm{pH}$ ) or 5.0 were incubated at temperatures ranging from 20 to $70^{\circ} \mathrm{C}$ at intervals of $10^{\circ} \mathrm{C}$ for $1 \mathrm{~h}$. For the influence of ethanol at different $\mathrm{pH}$, assay mixtures at $\mathrm{pH} 3.5$ or 5.0, with a series of final ethanol concentrations from $0 \%$ to $32 \%$ at intervals of $4 \%(\mathrm{v} / \mathrm{v})$, were incubated at $30^{\circ} \mathrm{C}$ for $1 \mathrm{~h}$.

\section{Statistical analysis}

The mean values of those replicated counts were subjected to analysis of variance using the statistical software SAS (SAS Institute, Cary, NC, USA) at a 1\% level of significance.

\section{RESULTS}

\section{Enzyme localization}

$\beta \mathrm{G}$ activity from different parts of strains SD-2a and 31MBR varied greatly, as shown in Table 1. Fairly low enzyme activity was detected in the culture supernatants and whole cell washes of both strains. After the sonication treatment, both the supernatants and the debris of the two strains displayed obvious activity, with the activity higher in the supernatants than in the debris, especially for strain $31 \mathrm{MBR}$. This may demonstrate that the $\beta \mathrm{G}$ from the two strains that was not secreted outside the cells was mainly intracellular in form and that some was adhered on the debris after the sonication treatment. In particular, great enzyme activity was detected on whole cells for strain SD-2a, much higher than that from the sonication supernatants or the debris, and almost equivalent to that observed in the disrupted lysate. For strain $31 \mathrm{MBR}$, on the other hand, the highest enzyme activity was observed in the sonication supernatants instead of the whole cells, which could be attributed to the release of $\beta \mathrm{G}$ after the sonication treatment. This result is in good agreement with the findings reported by Barbagallo et al. (2004b). Moreover, strain 31MBR possessed higher total $\beta \mathrm{G}$ activity (disrupted lysate activity) than strain SD-2a.

\section{Enzyme characterisations under different conditions}

As shown in Fig. 1, the influences of temperature, ethanol and $\mathrm{pH}$ on $\beta \mathrm{G}$ activity were conducted on disrupted lysate 
TABLE 1

$\beta$-D-glucosidase activities by location of enzyme activity for Oenococcus oeni strains.

\begin{tabular}{ccccrrrr}
\hline $\begin{array}{c}\text { Oenococcus } \\
\text { oeni } \text { strains }\end{array}$ & CS & WCW & WC & SS & DW & D & DL \\
\hline SD-2a & $0.05 \mathrm{~d}$ & $0.05 \mathrm{~d}$ & $7.67 \mathrm{a}$ & $4.35 \mathrm{~b}$ & $0.03 \mathrm{~d}$ & $2.75 \mathrm{c}$ & $7.48 \mathrm{a}$ \\
$31 \mathrm{MBR}$ & $0.04 \mathrm{c}$ & $0.07 \mathrm{c}$ & $1.38 \mathrm{c}$ & $18.37 \mathrm{~b}$ & $0.09 \mathrm{c}$ & $1.93 \mathrm{c}$ & $22.27 \mathrm{a}$ \\
\hline
\end{tabular}

CS, culture supernatants; WCW, whole cell washes; WC, whole cells; SS, sonication supernatants; DW, debris washes; D, debris; DL, disrupted lysate. Values are the averages of quadruplicate replications. Different letters within columns indicate significance at $P<0.01$. Means with the same letter are not significantly different. Activity is expressed as $\mu$ mol of $p$-NP liberated per min per gram of cell dry weight.

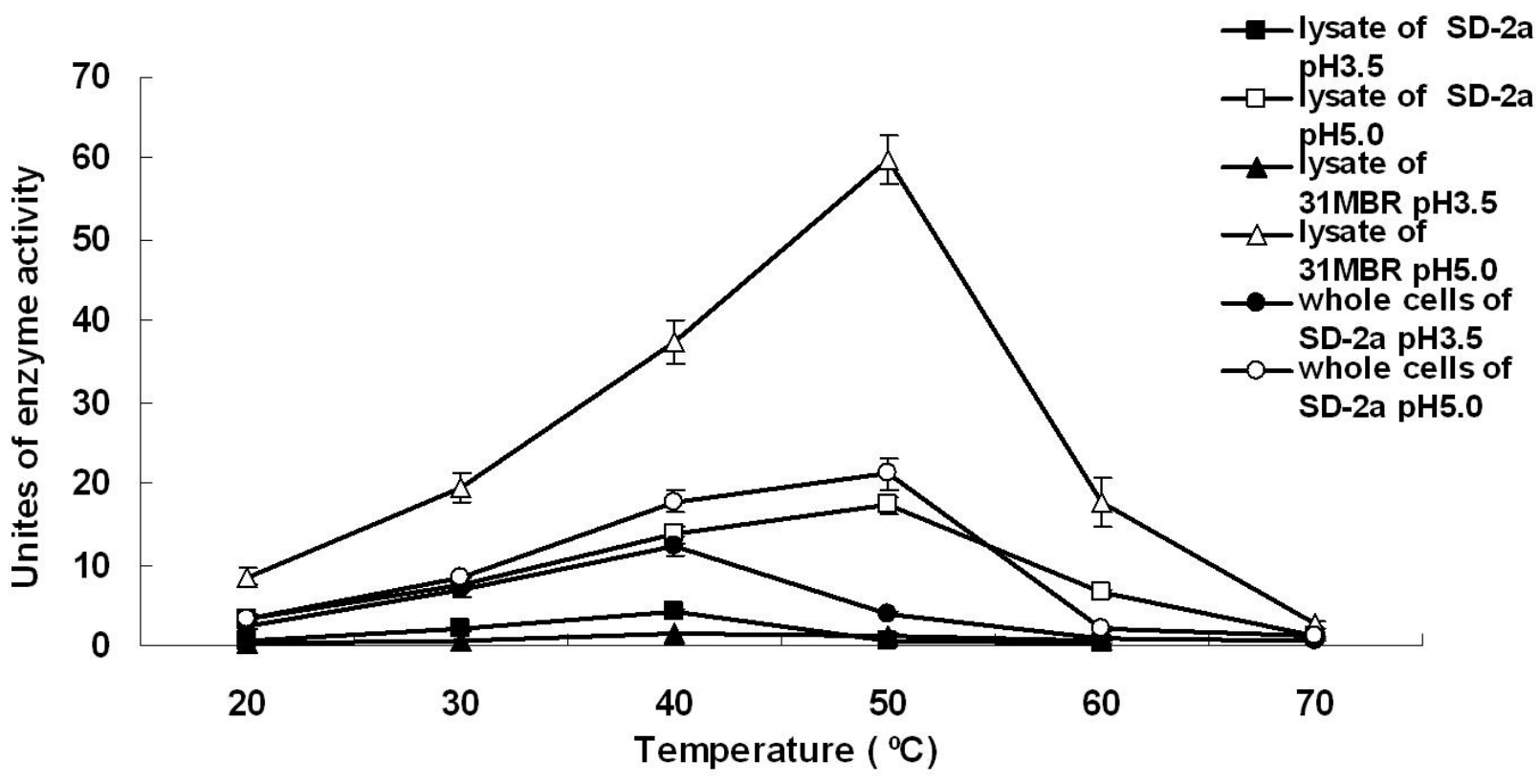

FIGURE 1A

In the present study, attention was focused on O. oeni strains SD-2a and 31MBR. Both strains are widely used in winemaking in China

of both strains as well as on whole cells of strain SD-2a, since these three samples displayed high activity in the enzyme location assay. The optimum temperature of $\beta \mathrm{G}$ activity from all the samples was $40^{\circ} \mathrm{C}$ at $\mathrm{pH} 3.5$ and $50^{\circ} \mathrm{C}$ at pH 5.0 (Fig. 1A). The influence of ethanol showed similar trends in three samples (Fig. 1B). The samples tested showed increased or retained high enzyme activity at low ethanol concentrations, and the enzyme activity decreased at high concentrations. Lysate of strain 31MBR showed high activity between ethanol concentrations of $16 \%$ to $20 \%$ at $\mathrm{pH} 5.0$. Such high ethanol tolerance for $\beta \mathrm{G}$ from $O$. oeni strains has not been reported, particularly at an ethanol concentration of $32 \%$, yet $20 \%$ of maximal activity remained. At $\mathrm{pH} 3.5$, whole cells of strain SD-2a still retained high activity at an ethanol concentration of $8 \%$. As to $\mathrm{pH}$, the samples showed higher activity at $\mathrm{pH} 5.0$ than that at $\mathrm{pH} 3.5$ in all treatments (Fig. 1A and B), and the optimum temperature (Fig. 1A) and ethanol tolerance (Fig. 1B) of the enzyme decreased at $\mathrm{pH}$ 3.5 compared with that at $\mathrm{pH}$ 5.0. This could be explained by previous reports that the optimum $\mathrm{pH}$ of $\beta \mathrm{G}$ was around 5.0 (Spagna et al., 1998; Grimaldi et al., 2000; Barbagallo et al., 2004a; González-Pombo et al., 2008; Michlmayr et al., 2010a), notwithstanding that an optimum $\mathrm{pH}$ of 3.8 has also been reported (Grimaldi et al., 2005b). In addition, at a wine- like $\mathrm{pH}$ of 3.5, whole cells of strain SD-2a had the highest activity under temperatures of 30,40 and $50^{\circ} \mathrm{C}$ (Fig. 1A) and ethanol concentrations of $0 \%, 4 \%$ and $8 \%$ (Fig. 1B) in all the samples tested.

\section{DISCUSSION}

In the present study, attention was focused on O. oeni strains SD-2a and 31MBR. Both strains are widely used in winemaking in China and possess important oenological characteristics, particularly being able to perform MLF effectively under winery conditions. Great physiological differences were observed between the two strains when cultured in ATB medium. It took strain SD-2a 80 h to reach the end of the exponential growth phase, while strain 31MBR needed only $40 \mathrm{~h}$ to reach the same stage. In addition, strain SD-2a was more fastidious than strain 31MBR about culture conditions. In order to assess the profile of $\beta \mathrm{G}$ from strains SD-2a and 31MBR, synthetic substrate $p$-nitrophenyl $\beta$-Dglucopyranoside was used in the study. However, some authors have pointed out that glycosidase assay depends to a large extent on the chemical structures of the substrate, and natural aroma precursors were recommended for an adequate evaluation of the glycosidases potential of the O. oeni strains (Gagné et al., 2011). 


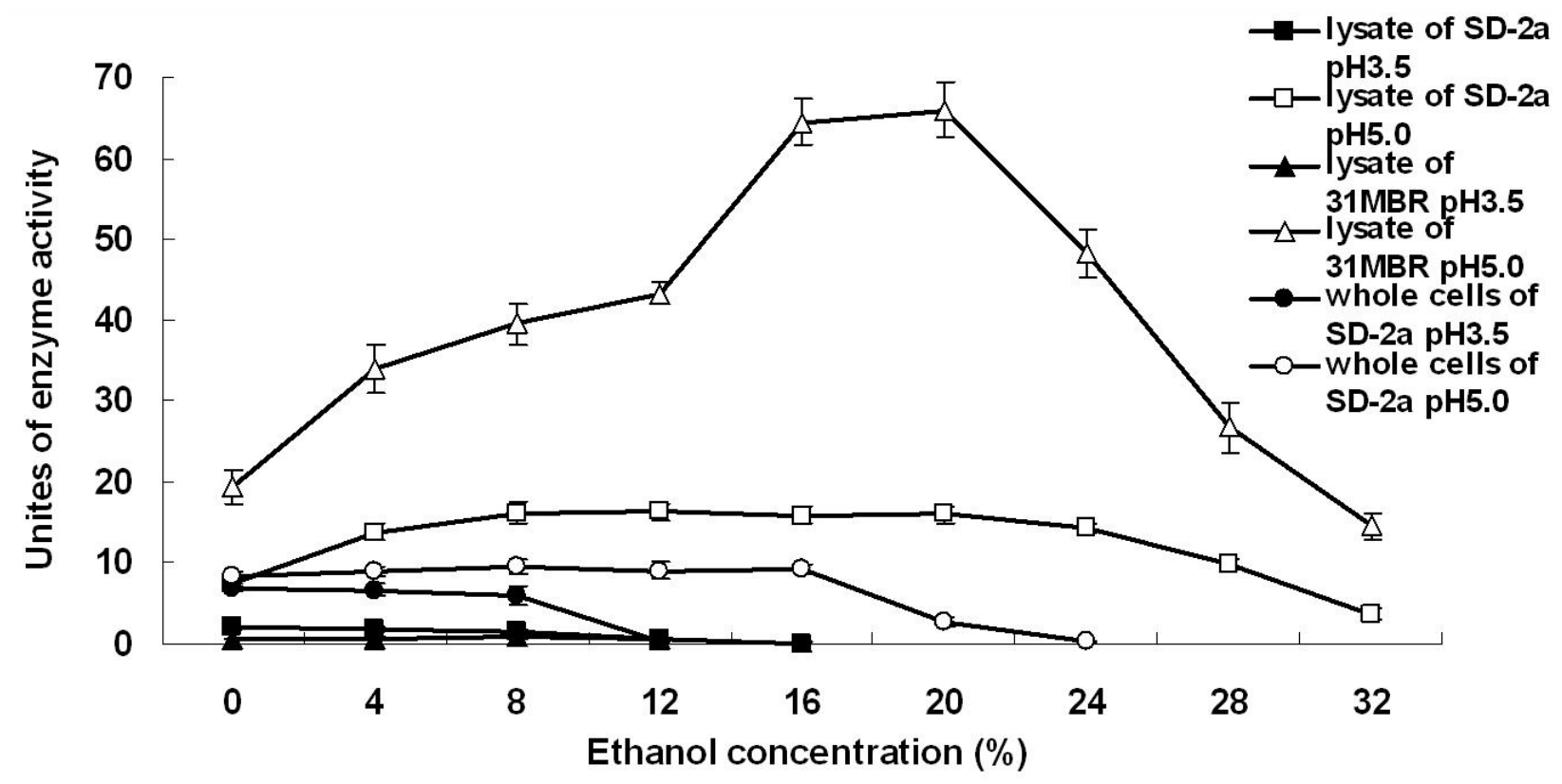

FIGURE 1B

In the present study, attention was focused on $O$. oeni strains SD-2a and 31MBR. Both strains are widely used in winemaking in China

Different $\beta \mathrm{G}$ activities were observed between $O$. oeni strains SD-2a and 31MBR in the present study. This confirms the previous reports that glycosidic activity was widespread and strain dependent among $O$. oeni strains (Mansfield et al., 2002; Grimaldi et al., 2005b). The result of intracellular enzyme activity for both strains is in good agreement with the findings reported on other $O$. oeni strains (Barbagallo et $a l ., 2004 \mathrm{~b}$ ). However, extracellular $\beta \mathrm{G}$ activity in $O$. oeni strains has also been observed (Mansfield et al., 2002). This seems to suggest that the location of $\beta \mathrm{G}$ in $O$. oeni strains is variable and strain dependent. However, it should be noted that considerable enzyme activity was detected on whole cells of strain SD-2a. Similar results, namely that whole cells of $O$. oeni strains possess high $\beta \mathrm{G}$ activity, have been reported (Grimaldi et al., 2000, 2005b; Michlmayr et al., 2010a). This could be explained by the presence of intracellular phospho- $\beta$-glucosidases and the phosphoenolpyruvatedependent phosphotransferase system (PEP-PTS). PEP-PTS is a bacterial transport system that allows bacterial cells to grow on various carbon sources, including $\beta$-glucosides (Deutscher et al., 2006). Capaldo et al. (2011) proposed that $O$. oeni was able to take up $\beta$-glucosides via a PEP-PTS involving phosphorylation and the subsequent hydrolysis of the phosphorylated glucosides in the cytoplasm through the action of phospho- $\beta$-glucosidases. The related genes bglA, B, $\mathrm{C}$ and D, encoding PEP-PTS components EIIC, EIIA, EIIB and phospho- $\beta$-glucosidase, have been studied (Capaldo et $a l ., 2011)$. Low enzyme activity of whole cells for $31 \mathrm{MBR}$ might be due to the lack of PEP-PTS. Thus it may be indicated that strain SD-2a is preferred to strain 31MBR for aroma enhancement in winemaking, since whole cells with great $\beta \mathrm{G}$ activity could be utilised directly in application. Strain $31 \mathrm{MBR}$, on the other hand, may be preferable for $\beta \mathrm{G}$ production due to the high total enzyme activity.

Based on the results of enzyme localisation that $\beta \mathrm{G}$ was the intracellular form for strains SD-2a and 31MBR, and that whole cells of strain SD-2a possessed high activity, disrupted lysate of both strains and whole cells of strain SD-2a were used to discover the influences of different physicochemical factors on $\beta \mathrm{G}$ activity. Temperature showed a similar influence on $\beta \mathrm{G}$ from all samples. At $\mathrm{pH} 3.5$, an optimum temperature of $40^{\circ} \mathrm{C}$ was observed. This means that, in winemaking practice, the temperature, which usually is controlled at about $25^{\circ} \mathrm{C}$ or lower, would have a negative effect on the enzyme activity. As for the influence of ethanol, some authors have reported that $\beta \mathrm{G}$ is a fairly stable enzyme in ethanol solvent (Spagna et al., 1998; Barbagallo et al., 2002; Palmeri \& Spagna, 2007), while others have suggested that ethanol is the cause of the inhibition of glycosidases (Winterhalter \& Skouroumounis, 1997; Grimaldi et al., 2000; Spagna et al., 2002; Barbagallo et al., 2004b).

In this study, $\beta \mathrm{G}$ activity was enhanced at low ethanol concentrations and inhibited at high concentrations. This is coincident with previous reports that ethanol at concentrations of $4 \%, 8 \%$ and $10 \%$ led to an enhancement of $\beta \mathrm{G}$ activity, while enzyme activity decreased sharply at even higher concentrations (Grimaldi et al., 2000; Barbagallo et al., 2004a, 2004b; Grimaldi et al., 2005b; González-Pombo et al., 2008). The enhancement behaviour of ethanol at low concentrations could be ascribed to the glycosyl transferase activity of $\beta \mathrm{G}$ (Pemberton et al., 1980; Barbagallo et al., 2004b). Ethanol increases reaction rates by acting as an acceptor of a key glycosyl intermediate. At high ethanol concentrations, the enzyme activity was most likely negatively affected by protein denaturation. It was also noticed that whole cell enzyme had a lower ethanol tolerance $(16 \%)$ than that of the lysate $(24 \%)$ for strain $\mathrm{SD}-2 \mathrm{a}$ at $\mathrm{pH}$ 5.0. This negative influence of ethanol at high concentrations on $\beta \mathrm{G}$ inside the cells might be achieved by its action on the cell membrane. Ethanol might have altered membrane permeability, resulting in difficult access between intracellular $\beta \mathrm{G}$ and the substrate (Grimaldi et al., 2000; 
Barbagallo et al., 2004b). pH generally is an important factor affecting enzyme activity; in fact, low $\mathrm{pH}$ is the main inhibitor of $\beta \mathrm{G}$ activity (Grimaldi et al., 2000; Barbagallo et al., 2004b). In the present experiment, $\beta \mathrm{G}$ activity from all samples decreased sharply at a $\mathrm{pH}$ of 3.5 , compared with that at a $\mathrm{pH}$ of $5.0 \mathrm{in}$ all the treatments. This may suggest that the $\beta \mathrm{G}$ activity from SD-2a and $31 \mathrm{MBR}$ could be negatively affected in winemaking (with a $\mathrm{pH}$ of around 3.5). However, at a wine-like $\mathrm{pH}$ of 3.5, whole cells of strain SD-2a still exhibited considerable activity, much higher than those from the lysate of strain SD-2a under different temperatures and ethanol concentrations. Therefore, strain SD-2a proves promising for flavour enhancement under oenological conditions and seems to be more suitable for the practice of winemaking.

\section{CONCLUSIONS}

$\beta \mathrm{G}$ was mainly intracellular form for $O$. oeni strains SD$2 \mathrm{a}$ and $31 \mathrm{MBR}$. Whole cells of strain SD-2a showed considerable enzyme activity, while strain $31 \mathrm{MBR}$ possessed higher total activity. Ethanol at low concentrations enhanced $\beta \mathrm{G}$ activity in both strains, but the activity was greatly inhibited under the wine-like $\mathrm{pH}$ of 3.5. Strain SD-2a, whole cells of which showed great enzyme activity under wine-like conditions, proved to have potential for aroma enhancement in oenological application. However, further study, using natural aroma precursors instead of synthetic substrates, is still needed for an adequate evaluation of the $\beta \mathrm{G}$ potential of strains SD-2a and 31MBR.

\section{LITERATURE CITED}

Barbagallo, R., Spagna, G., Abbate, C., Azzaro, G. \& Palmeri, R., 2002. Inexpensive isolation of $\beta$-D-glucopyranosidase from $\alpha$-Larabinofuranosidase, $\alpha$-L-rhamnopyranosidase, and $o$-acetylesterase. Appl. Biochem. Biotechnol. 101, 1-13.

Barbagallo, R., Spagna, G., Palmeri, R., Restuccia, C. \& Giudici, P., 2004a. Selection, characterization and comparison of beta-glucosidase from mould and yeasts employable for enological applications. Enz. Microb. Technol. 35, 58-66.

Barbagallo, R., Spagna, G., Palmeri, R. \& Torriani, S., 2004b. Assessment of $\beta$-glucosidase activity in selected wild strains of Oenococcus oeni for malolactic fermentation. Enz. Microb. Technol. 34, 292-296.

Bartowsky, E.J., Costello, P. \& Henschke, P.A., 2002. Management of malolactic fermentation - wine flavour manipulation. Aust. NZ. Grapegrower Winemaker 461, 7-8 \& 10-12.

Bloem, A., Lonvaud-Funel, A. \& De Revel, G., 2008. Hydrolysis of glycosidically bound flavour compounds from oak wood by Oenococcus oeni. Food Microbiol. 25, 99-104.

Boido, E., Lloret, A., Medina, K., Carrau, F. \& Dellacassa, E., 2002. Effect of $\beta$-glycosidase activity of Oenococcus oeni on the glycosylated flavor precursors of Tannat wine during malolactic fermentation. J. Agric. Food Chem. 50, 2344-2349.

Capaldo, A., Walker, M.E., Ford, C.M. \& Jiranek, V., 2011. $\beta$-Glucoside metabolism in Oenococcus oeni: cloning and characterisation of the phospho- $\beta$-glucosidase bglD. Food Chem. 125, 476-482.

Deutscher, J., Francke, C. \& Postma, P.W., 2006. How phosphotransferase system-related protein phosphorylation regulates carbohydrate metabolism in bacteria. Microbiol. Mol. Biol. Rev. 70, 939-1031.
D’Incecco, N., Bartowsky, E., Kassara, S., Lante, A., Spettoli, P. \& Henschke, P., 2004. Release of glycosidically bound flavour compounds of Chardonnay by Oenococcus oeni during malolactic fermentation. Food Microbiol. 21, 257-265.

Gagné, S., Lucas, P.M., Perello, M.C., Claisse, O., Lonvaud-Funel, A. \& De Revel, G., 2011. Variety and variability of glycosidase activities in an Oenococcus oeni strain collection tested with synthetic and natural substrates. J. Appl. Microbiol. 110, 218-228.

González-Pombo, P., Pérez, G., Carrau, F., Guisán, J.M., Batista-Viera, F.\& Brena, B.M., 2008. One-step purification and characterization of an intracellular $\beta$-glucosidase from Metschnikowia pulcherrima. Biotechnol. Lett. 30, 1469-1475.

Grimaldi, A., McLean, H. \& Jiranek, V., 2000. Identification and partial characterization of glycosidic activities of commercial strains of the lactic acid bacterium, Oenococcus oeni. Am. J. Enol. Vitic. 51, 362-369.

Grimaldi, A., Bartowsky, E. \& Jiranek, V., 2005a. Screening of Lactobacillus spp. and Pediococcus spp. for glycosidase activities that are important in oenology. J. Appl. Microbiol. 99, 1061-1069.

Grimaldi, A., Bartowsky, E. \& Jiranek, V., 2005b. A survey of glycosidase activities of commercial wine strains of Oenococcus oeni. Int. J. Food Microbiol. 105, 233-244.

Grimaldi, A., McLean, H. \& Jiranek, V., 2000. Identification and partial characterization of glycosidic activities of commercial strains of the lactic acid bacterium, Oenococcus oeni. Am. J. Enol. Vitic. 51, 362-369.

Maicas, S. \& Mateo, J.J., 2005. Hydrolysis of terpenyl glycosides in grape juice and other fruit juices: a review. Appl. Microbiol. Biotechnol. 67, 322 335 .

Maicas, S., Gil, J.V., Pardo, I. \& Ferrer, S., 1999. Improvement of volatile composition of wines by controlled addition of malolactic bacteria. Food Res. Int. 32, 491-496.

Mansfield, A.K., Zoecklein, B.W. \& Whiton, R.S., 2002. Quantification of glycosidase activity in selected strains of Brettanomyces bruxellensis and Oenococcus oeni. Am. J. Enol. Vitic. 53, 303-307.

Mateo, J. \& Jimenez, M., 2000. Monoterpenes in grape juice and wines. J. Chromatogr. A. 2000, 557-567.

McMahon, H., Zoecklein, B., Fugelsang, K. \& Jasinski, Y., 1999. Quantification of glycosidase activities in selected yeasts and lactic acid bacteria. J. Ind. Microbiol. Biotechnol. 23, 198-203.

Michlmayr, H., Schümann, C., Barreira Braz da Silva, N.M., Kulbe, K.D. \& Del Hierro, A.M., 2010a. Isolation and basic characterization of a $\beta$-glucosidase from a strain of Lactobacillus brevis isolated from a malolactic starter culture. J. Appl. Microbiol. 108, 550-559.

Michlmayr, H., Schümann, C., Wurbs, P., Barreira Braz da Silva, N.M., Rogl, V., Kulbe, K.D. \& Del Hierro, A.M., 2010b. A $\beta$-glucosidase from Oenococcus oeni ATCC BAA-1163 with potential for aroma release in wine: cloning and expression in E. coli. World J. Microbiol. Biotechnol. 26, 1281-1289.

Palmeri, R. \& Spagna, G., 2007. $\beta$-Glucosidase in cellular and acellular form for winemaking application. Enzyme Microb. Technol. 40, 382-389.

Pemberton, M.S., Brown, R.D. \& Emert, G.H., 1980. The role of $\beta$-glucosidase in the bioconversion of cellulose. Can. J. Chem. Eng. 58, $723-729$.

Saguir, F.M., Campos, I.E.L., Maturano, C. \& De Nadra, M.C.M., 2009. Identification of dominant lactic acid bacteria isolated from grape juices. Assessment of its biochemical activities relevant to flavor development in wine. Int. J. Wine Res. 1, 175-185. 
Spagna, G., Barbagallo, R.N., Greco, E., Manenti, I. \& Pifferi, P.G., 2002. A mixture of purified glycosidases from Aspergillus niger for oenological application immobilised by inclusion in chitosan gels. Enz. Microb. Technol. 30, 80-89.

Spagna, G., Romagnoli, D., Angela, M., Bianchi, G. \& Pifferi, P.G., 1998. A simple method for purifying glycosidases: $\alpha$-L-arabinofuranosidase and $\beta$-D-glucopyranosidase from Aspergillus niger to increase the aroma of wine. Part I. Enz. Microb. Technol. 22, 298-304.
Ugliano, M., Genovese, A. \& Moio, L., 2003. Hydrolysis of wine aroma precursors during malolactic fermentation with four commercial starter cultures of Oenococcus oeni. J. Agric. Food Chem. 51, 5073-5078.

Williams, P.J., Cynkar, W., Francis, I.L., Gray, J.D., Iland, P.G. \& Coombe, B.G., 1995. Quantification of glycosides in grapes, juices, and wines through a determination of glycosyl glucose. J. Agric. Food Chem. 43, 121-128.

Winterhalter, P. \& Skouroumounis, G., 1997. Glycoconjugated aroma compounds: occurrence, role and biotechnological transformation. Adv. Biochem. Eng. Biotechnol. 55, 73-105. 